\title{
Markers of serious illness in infants under 6 months old presenting to a children's hospital
}

\author{
P H Hewson, S M Humphries, D M Roberton, J M McNamara, M J Robinson
}

\begin{abstract}
Six hundred and eighty two assessments were performed on 641 babies under 6 months of age who presented to the emergency department of the Royal Children's Hospital, Melbourne, to try and determine the best markers of serious illness in young infants. Detailed, specific questions that quantified a baby's functional response to illness gave the most useful information. As a group, the six most common predictive symptoms of serious illness were: taking less than half the normal amount of feed over the preceding 24 hours, breathing difficulty, having less than four wet nappies in the preceding $\mathbf{2 4}$ hours, decreased activity, drowsiness, and a history of being both pale and hot. The presence of the corresponding sign on examination increased the predictive value of the symptom by $10-20 \%$. Specific, highly predictive (though less common) signs included moderate to severe chest wall recession, respiratory grunt, cold calves, and a tender abdomen. A list of low, medium, and high risk symptoms has been constructed and the five measurements that were most useful in predicting serious illness in young infants have been detailed.
\end{abstract}

The relative importance of many signs and symptoms in young, ill infants remains uncertain. ${ }^{1-5}$ The multicentre study of postneonatal mortality suggested that serious illness may not be recognised by parents or doctors, ${ }^{6}$ and Stanton et al highlighted 12 symptoms that seemed to be associated with sudden death. ${ }^{2}$ Controversy since then illustrates both the need for a systematic study of signs and symptoms in this age group, and validation of guidelines for parents and health workers responsible for the care of infants. ${ }^{4}$

Studies of feverish babies have shown that specific clinical findings lack predictive value, although a physician's 'impression of sepsis' was said to be useful. ${ }^{7-9}$ McCarthy et al have shown that several detailed observations can help to identify those feverish young children (aged 3 to 24 months) who have bacterial or viral infections. ${ }^{10}$ Attention to specific, detailed questions and precise definitions may permit more accurate interpretation of symptoms, both individually and in combination, when assessing all types of serious illness in young babies.

This paper presents a univariate analysis of the symptoms and signs of babies presenting to the Royal Children's Hospital, Melbourne, for assessment of possible illness. The initial aim was to determine the most predictive and sensi- tive markers of serious illness in babies under 6 months of age within the hospital.

\section{Patients and methods}

A total of 641 babies under 6 months of age were enrolled in a prospective study when they presented with acute illnesses of less than 15 days' duration to the emergency department, Royal Children's Hospital, Melbourne on three days of each week for a year. The hospital acts as a primary, secondary, and tertiary referral centre, and over 70000 children are assessed in the emergency department each year. A standardised initial assessment was performed by PHH that documented the nature of the presenting problem, and the presence or absence of 28 symptoms (table 1 ) and 46 signs. The symptoms were the variables identified by the parents on direct questioning, and the signs were the observations of-and findings onexamination of the baby by an experienced clinician (PHH) who also documented his initial impression of the degree of illness (normal, mild, moderate, or severe) after taking the history and carrying out the examination. If admission to hospital was thought likely, the admitting officer then assessed the baby and decided whether admission was necessary.

All infants who were admitted, and those who had rectal temperatures of $>38 \cdot 2^{\circ} \mathrm{C}$, had a standard set of investigations carried out (full blood examination, estimation of concentrations of urea and electrolytes, acid base, blood cultures, microscopy and culture of the urinesuprapubic aspirate if possible), together with any special investigation deemed clinically necessary-for example, lumbar puncture, chest radiograph, or barium enema examination.

To determine the outcome of the illness, the hospital records of all infants who were admitted were reviewed independently after discharge by three experienced paediatricians (JMMCN, MJR, and DMR) and the severity of the illness was graded using a seven point score. They retrospectively classified the babies as having required (i) hospital treatment, (ii) hospital observation, or (iii) home (parental) observation or care. This review included all the medical and nursing notes, the results of investigations, and the diagnosis at discharge. The review was carried out without knowledge of the initial documentation of symptoms and signs done by $\mathrm{PHH}$ (which were kept separately) and without knowledge of each other's opinions. A small number of babies who were not admitted to hospital also had their 
Table 1 Definitions of symptoms

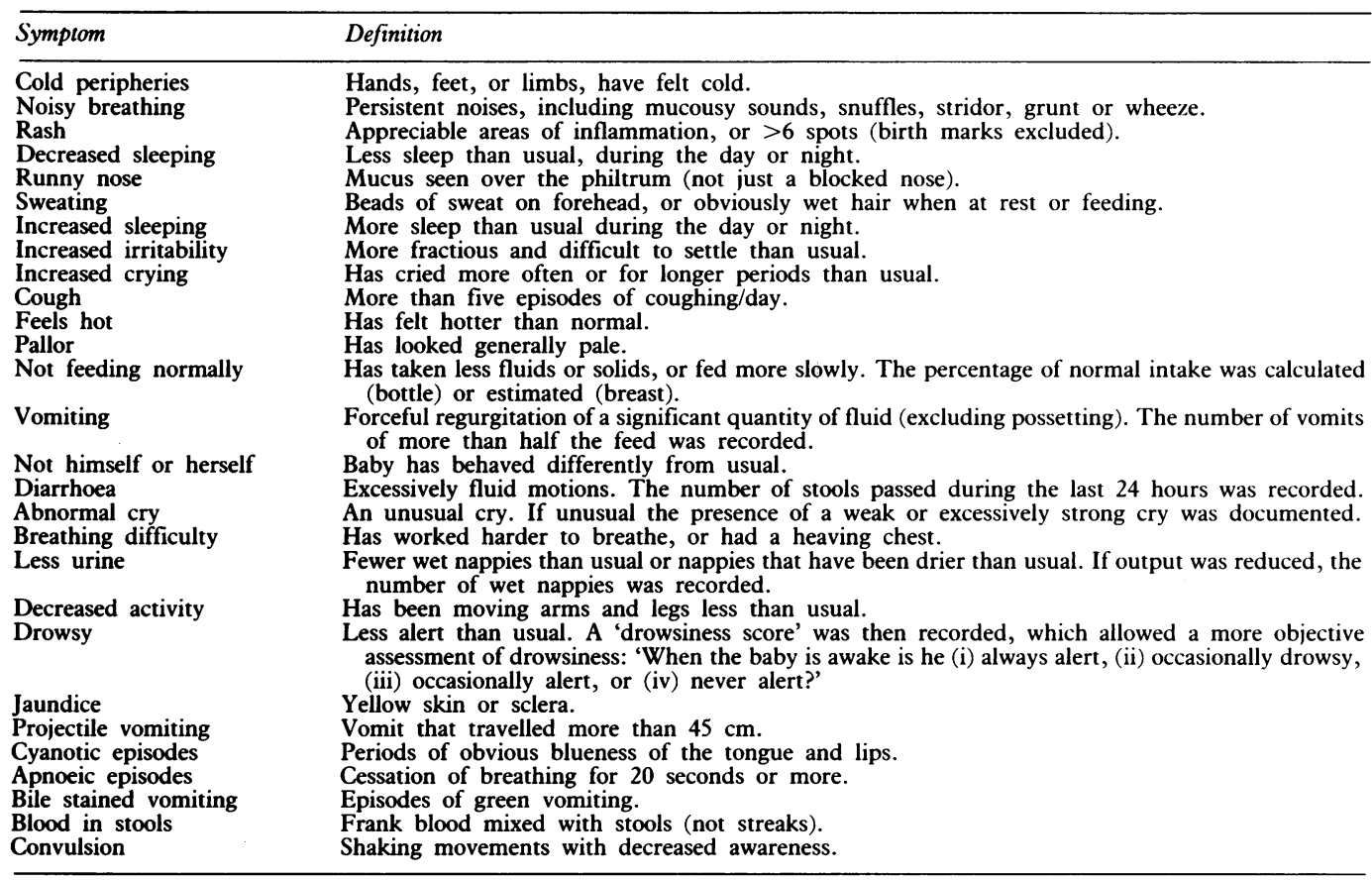

Symptoms were recorded only if they occurred within the previous 24 hours.

emergency department notes scored by the paediatricians.

All babies were seen daily for three days after the initial assessment whether in hospital or at home, and their functional state determined in a standard manner by independent research assistants. Any baby whose health was deteriorating at home was referred back to hospital for further assessment by the admitting officer.

A 50 page manual defining all symptoms and signs, procedures carried out, and study protocol was written and adhered to. Approval for the study was obtained from the hospital ethics committee.

\section{DEFINITION OF SERIOUS ILLNESS}

'Index definition' of serious illness-that is, needing observation in hospital

The illness was defined as serious if at least two of the three experienced paediatricians (JMMcN, MJR, and DMR) independently scored the infant as requiring observation in hospital after retrospective, independent review of the hospital recored. If the child was not admitted to hospital and the paediatricians did not review the hospital record, then PHH's grading of the illness as severe in the emergency department was used to define serious illness.

\section{Alternative definitions of serious illness}

Because of the difficulty in defining absolute criteria (or a 'gold standard') for serious illness, the results using the index definition of serious illness were compared with results using alternative definitions of serious illness. These alternative definitions were:

(i) When two or more of the same three paediatricians independently scored the hospital record of the baby (after discharge) as indicating the need for hospital treatment (intravenous fluids, parenteral antibiotics, oxygen, or surgery).

(ii) When a baby had a seriously abnormal laboratory result (serum concentrations of sodium $>149$ or $<128 \mathrm{mmol} / \mathrm{l}$, bicarbonate $>27$ or $<17 \mathrm{mmol} / 1$, or urea $>7 \cdot 0 \mathrm{mmol} / \mathrm{l} ; \mathrm{pH}>7.49$ or $<7 \cdot 28$; haemoglobin concentration $<80.0$ g/l, white cell count $>20 \times 10^{9} / 1$ (neutrophils $>10$ or $<1 \times 10^{9} / 1$, band count $\left.>2 \times 10^{9} / 1\right)$; culture of blood, urine, or cerebrospinal fluid growing a pathogen; abnormal chest radiograph (for example, segmental opacification) or an abnormal barium enema examination).

(iii) When PHH had scored the baby as being severely ill in the emergency department after documenting all the symptoms and signs. (This outcome contributed to the index definition but was also used independently as an alternative definition.)

\section{STATISTICAL ANALYSIS}

The demographic characteristics of the babies and the incidence and diagnostic measures (predictive values, sensitivity, and specificity) of each symptom and sign were determined (table 2). ${ }^{11}$ The diagnostic measures were initially calculated for the index definition of serious illness and these were then compared with those of each of the alternative definitions of serious illness. A checklist illustrating the relative risk of serious illness in the presence of various symptoms was developed. The most common (sensitive) predictive symptoms were also worked out.

\section{Results}

PATIENTS

Numbers and description

Six hundred and eighty two assessments were 
Table 2 Definitions used and methods of calculation

\begin{tabular}{|c|c|c|}
\hline Sensitivity & Percentage of people with disease who have positive test & $\frac{\text { True positive }}{\text { True positive }+ \text { false negative }} \times 100$ \\
\hline Specificity & Percentage of people without disease who have negative test & $\frac{\text { True negative }}{\text { True negative }+ \text { false positive }} \times 100$ \\
\hline Positive predictive value & Percentage of people with positive test who have disease & $\frac{\text { True positive }}{\text { True positive }+ \text { false positive }} \times 100$ \\
\hline Negative predictive value & $\begin{array}{l}\text { Percentage of people with negative test who do not have } \\
\text { disease }\end{array}$ & $\begin{array}{c}\text { True negative } \\
\text { True negative }+ \text { false negative }\end{array} \times 100$ \\
\hline
\end{tabular}

True positive $=$ test positive and disease present; false positive $=$ test positive and disease absent; false negative $=$ test negative and disease present; and true negative $=$ test negative and disease absent.

made on 641 babies, 346 (54\%) of whom were boys. Forty one infants had repeat assessments for different illnesses. The median age of the babies was 10 weeks and 5 days. Of the mothers, $79 \%$ were married and living with their husbands, and $9 \%$ were under 20 years of age. Eighteen per cent came from social classes I or II, $60 \%$ from class III non-manual or manual, $19 \%$ from class IV or V, and $3 \%$ were uncoded. ${ }^{13}$ At least one parent smoked cigarettes in $63 \%$ of the homes. Of the parents for whom the nationalities were known $(n=1361)$, $48 \%$ were Australian, $25 \%$ southern European, $12 \%$ central or northern European, $7 \%$ Asians, and $6 \%$ Middle Eastern. The mother's educational state was recorded for the last 501 infants assessed, and of these, $60 \%$ had not proceeded past the fourth year of secondary school.

\section{Referral pattern}

Doctors referred 130 (19\% of the assessments) and the remainder were self referred.

\section{History}

Forty two (.6\% of 681$)$ were born at less than 37 weeks' gestation, $16(2 \%)$ had a serious congenital abnormality, 13 (2\%) had evidence of previous developmental delay, and $55(8 \%)$ had had a previous hospital admission.

HOSPITAL ADMISSIONS AND DIAGNOSES

One hundred and fifty six (23\%) were admitted to hospital immediately, and another $22(3 \%)$

Table 3 Frequency, predictive values, sensitivity, and specificity of symptoms in 682 assessments (unless otherwise stated). Index definition was used for outcome and values given to nearest whole number

\begin{tabular}{|c|c|c|c|c|c|}
\hline \multirow[t]{2}{*}{ Symptom } & \multirow{2}{*}{$\begin{array}{l}\text { Frequency } \\
\text { (\% of total assessed) }\end{array}$} & \multicolumn{2}{|c|}{ Predictive values } & \multirow{2}{*}{$\begin{array}{l}\text { Sensitivity } \\
(\%)\end{array}$} & \multirow{2}{*}{$\begin{array}{l}\text { Specificity } \\
(\%)\end{array}$} \\
\hline & & $\begin{array}{l}\text { Positive } \\
(\%)\end{array}$ & $\begin{array}{l}\text { Negative } \\
(\%)\end{array}$ & & \\
\hline $\begin{array}{l}\text { Respiratory: } \\
\text { Cyanotic episode } \\
\text { Apnoeic episode } \\
\text { Breathing difficulty } \\
\text { Runny nose } \\
\text { Noisy breathing } \\
\text { Cough }\end{array}$ & $\begin{aligned} & 47(7) \\
& 35(5) \\
& 228(33) \\
& 235(34) \\
& 436(64) \\
& 351(51)\end{aligned}$ & $\begin{array}{l}70 \\
60 \\
40 \\
29 \\
27 \\
26\end{array}$ & $\begin{array}{l}76 \\
75 \\
79 \\
74 \\
73 \\
72\end{array}$ & $\begin{array}{l}18 \\
11 \\
49 \\
37 \\
64 \\
50\end{array}$ & $\begin{array}{l}97 \\
97 \\
72 \\
66 \\
36 \\
48\end{array}$ \\
\hline $\begin{array}{l}\text { Gastrointestinal and fluids: } \\
\text { Bile stained vomit } \\
\text { Not feeding: } \\
<34 \% \\
<50 \%(n=530) \\
34 \%-<67 \% \\
67 \%-99 \% \\
\text { Wet nappies }<4 \quad(n=654) \\
\text { Bloody stool } \\
\text { Less urine } \\
\text { Vomiting }>5 \text { time in previous } 24 \text { hours } \\
\text { Smelly urine }(n=502) \\
\text { Projectile vomiting } \\
\text { Diarrhoea }\end{array}$ & $\begin{aligned} & 5(1) \\
& 368(54) \\
& 27(5) \\
& 50(9) \\
& 175(26) \\
& 144(21) \\
& 44(6) \\
& 11(2) \\
& 111(16) \\
& 27(4) \\
& 95(19) \\
& 55(8) \\
& 226(33)\end{aligned}$ & $\begin{array}{l}100 \\
35 \\
73^{*} \\
62 \\
36^{*} \\
25 \\
66 \\
64 \\
50 \\
37 \\
33 \\
31 \\
26\end{array}$ & $\begin{array}{l}73 \\
82 \\
90 \\
75 \\
76 \\
72 \\
76 \\
74 \\
78 \\
73 \\
73 \\
73 \\
72\end{array}$ & $\begin{array}{r}3 \\
70 \\
17 \\
21 \\
34 \\
19 \\
16 \\
4 \\
31 \\
5 \\
17 \\
9 \\
31\end{array}$ & $\begin{array}{r}100 \\
52 \\
98 \\
96 \\
78 \\
78 \\
97 \\
99 \\
89 \\
97 \\
87 \\
92 \\
66\end{array}$ \\
\hline $\begin{array}{l}\text { Central nervous system: } \\
\text { Convulsions } \\
\text { Drowsy }\end{array}$ & $\begin{array}{c}10(1) \\
166(24)\end{array}$ & $\begin{array}{l}80 \\
59\end{array}$ & $\begin{array}{l}74 \\
83\end{array}$ & $\begin{array}{r}4 \\
54\end{array}$ & $\begin{array}{l}99 \\
86\end{array}$ \\
\hline $\begin{array}{l}\text { Drowsiness scale }(n=669) \\
\text { Always } \\
\text { Often } \\
\text { Occasional } \\
\text { Weak cry }(n=560) \\
\text { Decreased activity } \\
\text { Increased sleep } \\
\text { Abnormal cry } \\
\text { Not him/herself } \\
\text { Increased cry } \\
\text { Increased irritability } \\
\text { Decreased sleep }\end{array}$ & $\begin{aligned} & 6(1) \\
& 65(13) \\
& 85(17) \\
& 28(5) \\
& 113(20) \\
& 146(21) \\
& 389(57) \\
& 529(78) \\
& 477(70) \\
& 525(77) \\
& 346(51)\end{aligned}$ & $\begin{array}{l}83 \\
82 \\
45 \\
68 \\
64 \\
55 \\
33 \\
31 \\
30 \\
29 \\
27\end{array}$ & $\begin{array}{l}74 \\
80 \\
75 \\
75 \\
82 \\
81 \\
82 \\
88 \\
79 \\
78 \\
73\end{array}$ & $\begin{array}{l}3 \\
30 \\
21 \\
11 \\
47 \\
44 \\
71 \\
90 \\
76 \\
82 \\
50\end{array}$ & $\begin{array}{r}100 \\
98 \\
90 \\
98 \\
90 \\
87 \\
48 \\
27 \\
32 \\
25 \\
49\end{array}$ \\
\hline $\begin{array}{l}\text { Skin: } \\
\text { Pallor } \\
\text { Feels hot } \\
\text { Jaundice } \\
\text { Sweating } \\
\text { Cold periphery } \\
\text { Rash } \\
\text { Feels hot and pale }\end{array}$ & $\begin{aligned} & 236(35) \\
& 311(46)(1) \\
& 9(1) \\
& 248(36) \\
& 436(64) \\
& 225(33) \\
& 70(10)\end{aligned}$ & $\begin{array}{l}48 \\
36 \\
33 \\
32 \\
26 \\
24 \\
51\end{array}$ & $\begin{array}{l}84 \\
81 \\
73 \\
76 \\
71 \\
71 \\
79\end{array}$ & $\begin{array}{r}61 \\
61 \\
2 \\
43 \\
63 \\
29 \\
38\end{array}$ & $\begin{array}{l}75 \\
60 \\
99 \\
66 \\
34 \\
65 \\
86\end{array}$ \\
\hline
\end{tabular}

* The positive predictive value of serious illness for feeding $<34 \%$ of normal was $69 \%$ for bottle fed babies and $86 \%$ for breast fed babies. For feeding $34 \%-67 \%$ of normal, the figures were $37 \%$ and $34 \%$, respectively. 
Table 4 Frequency, predictive values, sensitivity, and specificity of the signs on examination in 682 assessments (unless otherwise stated). Index definition was used for outcome and values given to nearest whole number

\begin{tabular}{|c|c|c|c|c|c|}
\hline \multirow[t]{2}{*}{ Signs } & \multirow[t]{2}{*}{ No (\%) } & \multicolumn{2}{|c|}{ Predictive values } & \multirow{2}{*}{$\begin{array}{l}\text { Sensitivity } \\
(\%)\end{array}$} & \multirow{2}{*}{$\begin{array}{l}\text { Specificity } \\
(\%)\end{array}$} \\
\hline & & $\begin{array}{l}\text { Positive } \\
\text { (\%) }\end{array}$ & $\begin{array}{l}\text { Negative } \\
\text { (\%) }\end{array}$ & & \\
\hline \multirow{4}{*}{$\begin{array}{l}\text { Respiratory: } \\
\text { Central cyanosis } \\
\text { Grunt } \\
\text { Recession: } \\
\text { Moderate to severe } \\
\text { Any } \\
\text { Mild } \\
\text { Crepitations } \\
\text { Hyperinflation } \\
\text { Stridor } \\
\text { Wheeze } \\
\text { Tympanic membrane: } \\
\text { Injection } \\
\text { Acute or chronic otitis media } \\
\text { Mucousy breathing } \\
\text { Nasal discharge } \\
\text { Respiration rate (awake, breaths/minute) } \\
<40-59 \\
<40-59 \\
60-79 \\
80-99 \\
>100\end{array}$} & $\begin{array}{r}8(1) \\
11(2)\end{array}$ & $\begin{array}{l}100 \\
100\end{array}$ & $\begin{array}{l}74 \\
74\end{array}$ & $\begin{array}{l}4 \\
6\end{array}$ & $\begin{array}{l}100 \\
100\end{array}$ \\
\hline & $\begin{aligned} & 33(5) \\
& 267(40) \\
& 234(35) \\
& 27(4) \\
& 48(7) \\
& 15(2) \\
& 65(10)\end{aligned}$ & $\begin{array}{l}85 \\
42 \\
36 \\
63 \\
60 \\
53 \\
45\end{array}$ & $\begin{array}{l}76 \\
83 \\
83 \\
74 \\
75 \\
74 \\
75\end{array}$ & $\begin{array}{r}15 \\
61 \\
46 \\
9 \\
16 \\
4 \\
16\end{array}$ & $\begin{array}{l}99 \\
69 \\
69 \\
98 \\
96 \\
99 \\
93\end{array}$ \\
\hline & $\begin{aligned} 42(6) \\
30(5) \\
170(25) \\
34(5)\end{aligned}$ & $\begin{array}{l}31 \\
27 \\
29 \\
24\end{array}$ & $\begin{array}{l}74 \\
87 \\
73 \\
73\end{array}$ & $\begin{array}{r}7 \\
5 \\
27 \\
4\end{array}$ & $\begin{array}{l}90 \\
96 \\
76 \\
95\end{array}$ \\
\hline & $\begin{array}{r}68(10) \\
293(44) \\
225(33) \\
73(11) \\
15(2)\end{array}$ & $\begin{array}{l}41 \\
24 \\
28 \\
26 \\
13\end{array}$ & $\begin{array}{l}71 \\
70 \\
74 \\
73 \\
73\end{array}$ & $\begin{array}{r}15 \\
38 \\
35 \\
10 \\
1\end{array}$ & $\begin{array}{l}88 \\
54 \\
67 \\
89 \\
97\end{array}$ \\
\hline \multirow{2}{*}{$\begin{array}{l}\text { Abdominal: } \\
\text { Abdomen tender } \\
\text { Mass palpable } \\
\text { Inguinal hernia } \\
\text { Distended and tense } \\
\text { Liver size: } \\
>2.5 \mathrm{~cm} \\
\text { Palpable spleen }\end{array}$} & $\begin{array}{l}28(4) \\
15(2) \\
10(1) \\
20(3)\end{array}$ & $\begin{array}{l}96 \\
90 \\
80 \\
55\end{array}$ & $\begin{array}{l}76 \\
74 \\
74 \\
74\end{array}$ & $\begin{array}{r}15 \\
5 \\
4 \\
6\end{array}$ & $\begin{array}{l}99 \\
99 \\
99 \\
98\end{array}$ \\
\hline & $\begin{array}{l}312(49) \\
111(17)\end{array}$ & $\begin{array}{l}38 \\
28\end{array}$ & $\begin{array}{l}77 \\
73\end{array}$ & $\begin{array}{l}34 \\
17\end{array}$ & $\begin{array}{l}81 \\
84\end{array}$ \\
\hline $\begin{array}{l}\text { Central nervous system and arousal: } \\
\text { Awareness decreased } \\
\text { Cry quality weak } \\
\text { Eye fixation decreased } \\
\text { Posture abnormal } \\
\text { Hypotonia } \\
\text { Duration of cry increased }\end{array}$ & $\begin{array}{c}64(9) \\
55(8) \\
65(10) \\
58(9) \\
162(24) \\
285(42)\end{array}$ & $\begin{array}{l}89 \\
87 \\
86 \\
78 \\
48 \\
42\end{array}$ & $\begin{array}{l}79 \\
78 \\
79 \\
78 \\
80 \\
83\end{array}$ & $\begin{array}{l}31 \\
26 \\
30 \\
24 \\
44 \\
64\end{array}$ & $\begin{array}{l}99 \\
99 \\
98 \\
97 \\
83 \\
67\end{array}$ \\
\hline \multirow[b]{2}{*}{$\begin{array}{l}\text { Skin: } \\
\text { Delayed chest wall capillary return } \\
\text { Cold periphery: } \\
\text { Calves } \\
\text { Feet } \\
\text { Signs of dehydration } \\
\text { Generalised pallor } \\
\text { Sweating } \\
\text { Skin mottling } \\
\text { Bleeding into skin } \\
\text { Peripheral cyanosis } \\
\text { Peripheral pallor } \\
\text { Soft tissue mass } \\
\text { Delayed peripheral return } \\
\text { Pale conjunctivae } \\
\text { Rash }\end{array}$} & $7(1)$ & 86 & 74 & 3 & 99 \\
\hline & $\begin{aligned} & 24(4) \\
& 217(32) \\
& 24(4) \\
& 95(14) \\
& 11(2) \\
& 38(6) \\
& 7(1) \\
& 47(7) \\
& 116(17) \\
& 23(3) \\
& 151(22) \\
& 12(2) \\
& 96(13)\end{aligned}$ & $\begin{array}{l}79 \\
28 \\
75 \\
68 \\
64 \\
58 \\
57 \\
55 \\
51 \\
47 \\
41 \\
33 \\
22\end{array}$ & $\begin{array}{l}75 \\
76 \\
75 \\
80 \\
74 \\
75 \\
73 \\
75 \\
78 \\
73 \\
77 \\
73 \\
72\end{array}$ & $\begin{array}{r}10 \\
33 \\
10 \\
35 \\
4 \\
12 \\
2 \\
14 \\
32 \\
5 \\
34 \\
2 \\
12\end{array}$ & $\begin{array}{l}99 \\
68 \\
99 \\
94 \\
99 \\
97 \\
99 \\
96 \\
89 \\
98 \\
82 \\
98 \\
85\end{array}$ \\
\hline \multicolumn{6}{|l|}{$\begin{array}{l}\text { Other: } \\
\text { Rectal temperature }\left({ }^{\circ} \mathrm{C}\right)\end{array}$} \\
\hline $\begin{array}{l}<38 \cdot 3 \\
>38 \cdot 2-38 \cdot 9 \\
>38 \cdot 9\end{array}$ & $\begin{array}{l}606(89) \\
39(5) \\
36(5)\end{array}$ & $\begin{array}{l}22 \\
58 \\
68\end{array}$ & $\begin{array}{l}40 \\
75 \\
75\end{array}$ & $\begin{array}{l}72 \\
14 \\
14\end{array}$ & $\begin{array}{l}6 \\
96 \\
98\end{array}$ \\
\hline $\begin{array}{l}\text { Pulse (beats/minute): } \\
>199\end{array}$ & $31(5)$ & 67 & 75 & 11 & 98 \\
\hline
\end{tabular}

within three days; a wide range of diagnoses were encountered in these babies, which included 74 with upper respiratory tract infections, 62 with gastroenteritis, 45 with bronchiolitis, 44 with infant distress or colic, 17 with urinary tract infections, 11 with intussusception, nine with meningitis (seven of which were viral), six with septicaemia or bacteraemia, and six with cardiac failure, metabolic encephalopathy, or cerebral haemorrhage. Sixteen infants required operations for conditions that varied from phimosis and inguinal hernia to intestinal malrotation, perforated Meckel's diverticulum, and diaphragmatic hernia.

Two infants died in hospital, one from complex congenital cardiac disease and the other from cerebral haemorrhage complicating liver failure secondary to previously unrecognised biliary atresia. All other babies enrolled in the study were alive at 12 months of age.
CORRELATION OF PRESENTING PROBLEMS AND SYMPTOMS

Symptoms such as convulsions, coughing, vomiting, poor feeding, bloody stools, and apnoea were mentioned by the mother in over $40 \%$ of the babies in whom the symptom was present. Symptoms mentioned on less than $10 \%$ of occassions when the symptom was present were weak cry, increased sleeping, decreased activity, and drowsiness. Drowsiness was mentioned as a problem significantly more often by mothers in social classes I and II of Australian nationality $(p<0.05)$, but was not associated with maternal education, previous children, not smoking, or marital state.

NUMBER OF SERIOUSLY ILL INFANTS

Overall, $185(27 \%)$ infants were considered to 
Table 5 Checklist of symptoms present in previous 24 hours that assist in recognition of serious illness. Actual numerical values relevant only to Royal Children's Hospital

\begin{tabular}{|c|c|c|c|}
\hline & $\begin{array}{l}\text { Lower risk (positive } \\
\text { predictive value }<35 \% \text { ) }\end{array}$ & $\begin{array}{l}\text { Medium risk (positive } \\
\text { predictive value } 35-49 \%)\end{array}$ & $\begin{array}{l}\text { Higher risk (positive } \\
\text { predictive value }>49 \% \text { ) }\end{array}$ \\
\hline $\begin{array}{l}\text { Feeding } \\
\text { Central nervous system and arousal }\end{array}$ & $\begin{array}{l}>^{2 / 3} \text { Normal } \\
\text { Increased irritability } \\
\text { Decreased sleeping }\end{array}$ & $\begin{array}{l}1 / 2-2 / 3 \text { Normal } \\
\text { Occasionally drowsy }\end{array}$ & $\begin{array}{l}<1 / 2 \text { Normal } \\
\text { Often drowsy } \\
\text { Increased sleeping } \\
\text { Weak cry } \\
\text { Decreased activity } \\
\text { Convulsions }\end{array}$ \\
\hline & Cough & Breathing difficulty & $\begin{array}{l}\text { Apnoeic episode(s) } \\
\text { Cyanotic episode(s) }\end{array}$ \\
\hline Skin and circulation & $\begin{array}{l}\text { Cold feet } \\
\text { Feeling hot }\end{array}$ & Pale & Pale and hot \\
\hline Fluid output & $\begin{array}{l}\text { Five or less vomits in } \\
24 \text { hours } \\
\text { Diarrhoea }\end{array}$ & $\begin{array}{l}\text { More than five vomits in } \\
24 \text { hours } \\
\text { Less urine than usual }\end{array}$ & $\begin{array}{l}\text { Vomiting green fluid } \\
\text { Bloody stool } \\
\text { Less than four wet } \\
\text { nappies in } 24 \text { hours }\end{array}$ \\
\hline
\end{tabular}

be seriously ill when the index definition was used (needing hospital observation). Of these, 75 (11\% of the total) needed hospital treatment, and 110 needed observation alone. One hundred and fourteen $(17 \%)$ had at least one abnormal investigation result. $\mathrm{PHH}$ classified 160 (23\%) as seriously ill, $232(34 \%)$ as moderately ill, $246(36 \%)$ as mildly ill, and $44(7 \%)$ as normal after the initial assessment.

\section{SYMPTOMS AND SIGNS}

The frequency, predictive value, sensitivity, and specificity of each of the symptoms and signs using the index definition of serious illness are shown in tables 3 and 4 .

The positive predictive values of each symptom and sign using the alternative outcome criteria were also calculated. Although the absolute value changed with each outcome criterion, it was found that the symptom's order of risk of serious illness remained the same. The main exception was that apnoea was thought to indicate a higher risk by the experienced paediatricians compared with the alternative outcome criteria.

SYMPTOMS OF LOWER, MEDIUM, AND HIGHER RISK FOR SERIOUS ILLNESS

The symptoms were graded into lower, medium, and higher risk categories by their predictive values. The cutoff level of the predictive value differed according to which outcome criterion was used, though the relative order of risk remained the same. Using the index definition (need for hospital observation), the medium to higher risk cutoff was set at $50 \%$, and the lower medium risk cutoff was set at $35 \%$. Checklists of lower, medium, and higher risk symptoms were thus developed, and are shown in tables 5 and 6 . The predictive value of various pairs of symptoms in the medium risk group was calculated, and the combination with

Table 6 Specifications of the system using index definitions and with at least one group of symptoms (table 5) present

\begin{tabular}{|c|c|c|}
\hline & $\begin{array}{l}\text { High risk } \\
\text { group alone (\%) }\end{array}$ & $\begin{array}{l}\text { High and medium } \\
\text { risk groups (\%) }\end{array}$ \\
\hline $\begin{array}{l}\text { Positive predictive value } \\
\text { Negative predictive value } \\
\text { Sensitivity } \\
\text { Specificity } \\
\text { False positive rate } \\
\text { False negative rate }\end{array}$ & $\begin{array}{r}50 \\
88 \\
77 \\
72 \\
20 \\
6\end{array}$ & $\begin{array}{l}34- \\
99 \\
99 \\
32 \\
50 \\
0 \cdot 2\end{array}$ \\
\hline
\end{tabular}

a positive predictive value $>49 \%$ was feeling hot and looking pale. This combination was added to the list of symptoms and its diagnostic measure is shown in table 3.

If any one of the higher risk symptoms was present (right hand column of table 5) in hospital, this system has a sensitivity of $77 \%$, a specificity of $72 \%$, and a positive predictive value of risk of serious illness of $50 \%$.

If babies with inguinal hernias are excluded, only one infant was considered to require admission to hospital but not have a symptom designated either medium or high risk. The mother was, however, thought to be unreliable and the final diagnosis was 'non-accidental injury'.

\section{COMMON PREDICTIVE MARKERS OF ILLNESS}

The six most common, predictive symptoms in the seriously ill infants were: drowsiness, breathing difficulty, decreased activity, taking less than half the normal feed in the previous 24 hours, having less than four wet nappies in the previous 24 hours, and feeling hot when looking pale. Using the index definition of serious illness, $88 \%$ of the ill infants had at least one of these symptoms (sensitivity $88 \%$ ); the specificity was $55 \%$, and the positive predictive value was $41 \%$.

\section{SIGNS ON EXAMINATION}

The signs on examination that were recorded by PHH were $10 \%$ to $20 \%$ more predictive than the corresponding symptoms (table 4).

The signs indicating the highest risk of admission to hospital (positive predictive value above $65 \%$ ) were: respiratory-cyanosis, grunt, and moderatesevere recession; abdominaltenderness, palpable mass; central nervous system and arousal-decreased awareness or eye fixation, weak cry, or hypotonic posture; skincold calves, generalised pallor, sunken eyes or dry mucous membranes; and other: rectal temperature above $38.9^{\circ} \mathrm{C}$.

\section{Discussion}

This is to our knowledge the first large, prospective study of acute symptoms and signs in young infants. The main impediment to such a study in the past has been the lack of generally 
accepted standards of serious illness. We overcame the problem by comparing the results using a main index definition (the need for observation in hospital) to several alternative definitions of serious illness. For the first time, systematically determined markers of serious illness in young infants have been established.

The limitations of the study do, however, need to be acknowledged. Firstly, the babies studied were presenting to a children's hospital for assessment of illness and the results are not necessarily applicable to other communities because of the social background, referral patterns, and disease prevalence factors. Thus further studies are required using different observers in other hospitals to confirm the results.

Secondly, different types of bias were present in all the outcome measures used. ${ }^{14}$ Total outcome independence was not possible when no objective, well recognised, persistently relevant standard was available. Diagnostic review bias, recruitment bias, 'workup' bias, and incorporation bias are all in themselves important. Although each was present to some degree it was of a different type in each case, and the order of predictive symptoms remained the same, suggesting that the results are robust enough to overcome this difficulty in design.

\section{MOST USEFUL MEASUREMENT}

Analysis of a baby's functioning was most important when assessing the presence of serious illness. The most consistently predictive and sensitive factors were, firstly, the baby's ability to feed and, secondly, the baby's ability to respond, wake normally, be active, and cry strongly - that is, the baby's ability to arouse. Certainly the often forgotten paediatric adage 'beware the quiet baby' has been validated. Coughing, vomiting, or diarrhoea were not as important unless the baby was not functioning well according to the other criteria mentioned above.

Overall the following variables proved to be the most likely to help us decide whether serious illness was present: responsiveness and activity, feeding ability, breathing, urine output, and circulation when febrile.

Specific, relevant, and detailed questions must be asked so that these variables can be quantified. For example, the feeding ability needs to be known in detail-that is, the actual percentage of feed taken during the previous 24 hours compared with the baby's normal amount of feed. When mothers who were breast feeding were asked to scale their baby's feeding ability 0-10 (considering the time of active sucking and frequency of feeds), scores of less than 4 were at least as predictive of serious illness as if a baby receiving formula feed took less than $34 \%$ of his normal 24 hour volume. Similarly, a baby said to be passing less urine than normal had a $50 \%$ risk of being thought to need admission to hospital, compared with a $66 \%$ risk if less than four wet nappies had been noted. Thus detailed, quantification of certain functions was remarkably predictive of serious illness.

The recognition of obvious (moderate to severe) chest wall recession would greatly improve the assessment of the ability to breathe (positive predictive value $85 \%$ compared with 40\%). Further studies are required to assess whether parents and inexperienced health workers are able to recognise 'obvious' chest wall recession. That increasing respiratory rate was not predictive was probably the result of several factors. Firstly, the respiratory rate was counted using a stethoscope when the baby was at rest and awake. This was invariably $20-50 \%$ higher than the respiratory rate counted by nursing staff from the side of the cot. Without the stethoscope only breaths with larger volumes of air were counted, while the stethoscope allows smaller, panting breaths to be noticed. Secondly, there is a group of well babies aged between 2 weeks and 4-5 months who consistently breathe at 70-100 breaths/ minute while at rest and while awake. These babies (who were well and usually active, alert, and content) made the higher respiratory rates less predictive. Thirdly, although 45 babies had bronchiolitis only four definitely had pneumonia, thus illness prevalence factors may also have contributed to the finding.

The tendency for parents to mention the more graphic symptoms (such as convulsions, vomiting, coughing, and diarrhoea) rather than those associated with quietening may have been the results of minor language difficulty in some cases. Perception of the doctor's expectations, however, interference with their own lives, or lack of experience and knowledge, are other possible reasons. This finding itself illustrates the need to teach parents that the behavioural and functional responses of their baby to stress or illness are more important than the presence of a cough, vomit, or diarrhoea.

The lower, medium, and higher risk symptoms given in table 5 could be colour coded and-with the inclusion of definitions and suitable guidelines suggesting further actioncould ultimately provide a simple reference chart to check against when assessing for illness in young infants. It has the advantage of being based on information taken from parents and so could be given back to them without any further testing. It could, however, be made more sensitive, specific, and predictive if examination signs such as chest wall recession were included. Further field trials and education of parents would then be required before it could be distributed for general use.

The actual predictive values of the individual variables (and also of the checklist) are not relevant outside the hospital. It is likely, however, that the order of risk of symptoms will be similar in the community served by that hospital. Certainly, once they have attended the hospital the ability to compare the degree of risk for triage is useful. For example, $23 \%$ of infants were initially admitted to hospital. The presence of any symptom in the high risk column increases the risk of needing admission to $50 \%$-that is a positive predictive value of $50 \%$. Thus by using the checklist within the hospital it is possible to more than double the rate of recognition of infants who need to be in hospital.

The low specificity of the common markers 
and the checklist should not be overinterpreted. The fact that some babies with these symptoms were not regarded as having serious illness does not necessarily mean the medical assessment was not warranted. Advice about management (including the need for review) are important reasons for asking medical opinion.

In summary, by using clinically relevant definitions of serious illness, and with strict attention to detail, the most predictive and sensitive symptoms and signs of serious illness in babies presenting to a children's hospital have been determined. Further work needs to be carried out to ensure that these markers of serious illness are applicable in different communities with different observers.

This study was part of the collaborative Baby Illness Research pen in conjunction with the department of paediatrics, University of Cambridge, and we thank Drs CJ Morley, AJ Thornton, TJ Cole, R Powell, S Bechervaise, C Hewson, M Fowler and Professor PD Phelan as well as the staff of the emergency department, general clinic, medical records, and the departments of immunology, haematology, micrecords, and the departments of immunology, haematology, microbiology, and biochemistry, Royal Children's Hospital, Melbourne. The study was funded in Australia by the Australian Institute of Health (Australian government), Ross Trust, Felton and the A Williams Private Fund.
1 McWeeney PM, Emery JL. Unexpected post neonatal deaths (cot deaths) due to recognizable disease. Arch Dis Child (cot deaths) due

2 Stanton AN, Downham MAPS, Oakley JR, Emery JL, Knowelden $J$. Terminal symptoms in children dying suddenly and unexpectedly at home: preliminary report of the DHSS multicentre study of post neonatal mortality. $B$ Med F 1978;ii:1249-51.

3 Oakley JR, McWeeney PM, Hayes-Allen M, Emery JL. Possibly avoidable deaths in hospital in the age group one week to two years. Lancet 1976;i:770-2.

4 Valman B. Preventing infant deaths. Br Med F 1985;290 $339-40$.

5 Thurtle OA, Cox P, Fall C, et al. Preventing infant deaths. $B$ Med f 1985;290:1434-5.

6 Knowelden J, Keeling J, Nichol JP. A multicentre study of post neonatal mortality. London: Department of Health and Social Security, 1985.

7 Waskerwitz S, Berkelhamer JE. Outpatient bacteremia: clinical findings in children under two years with initial tempercal findings in children under two years with initial temper-

8 Dagan R, Powell KR, Hall CB, Menegus MA. Identification of infants unlikely to have serious bacterial infection of infants unlikely to have serious bacterial infection although hos

9 Crain EF, Shelov SP. Febrile infants: predictors of bacteremia. If Pediatr 1982;101:686-9.

10 McCarthy PL, Sharpe MR, Spiesel SZ, et al. Observation scales to identify serious illness in febrile children. Pediat rics 1982;70:802-9.

11 Selker HP. Clinical prediction rules. N Engl F Med 1986;314 714-5.

12 Sackett DL, Haynes RB, Tugwell P. Clinical epidemiology. A basic science for clinical medicine. Boston: Little, Brown and Co, 1985.

13 Office of population censuses and surveys. Classification of occupations. London: HMSO, 1980.

14 Ransolf DF, Feinstein AR Problems of spectrum and bias in evaluating the efficacy of diagnostic tests. $N$ Engl $\mathcal{Y}$ Med 1978;299:926-30. 